8 - ORIGINAL ARTICLE

WOUND HEALING

\title{
Evaluation of liver regeneration with use of diet supplemented with l-arginine ${ }^{1}$
}

\author{
Widlani Sousa Montenegro ${ }^{\mathrm{I}}$, Osvaldo Malafaia ${ }^{\mathrm{II}}$, Paulo Afonso Nunes Nassif ${ }^{\mathrm{II}}$, Luciane Bugmann Moreira' ${ }^{\mathrm{III}}$, Manoel Alberto \\ Prestes $^{\text {IV }}$, Márcio Hiroaki Kume ${ }^{\mathrm{v}}$, Leandro Bressianini Jurkonis ${ }^{\mathrm{VI}}$, Igor Furlan Cella ${ }^{\mathrm{VI}}$
}

DOI: http://dx.doi.org/10.1590/S0102-8650201400150008

IMaster, FEPAR, Curitiba-PR, Brazil. Conception and design of the study, critical revision.

${ }^{I I P h D}$, Full Professor, FEPAR, Federal University of Parana (UFPR), Curitiba-PR, Brazil. Supervised all phases of the study, manuscript writing, critical revision.

IIIPhD, Associate Professor, UFPR, Curitiba-PR, Brazil. Manuscript writing, critical revision.

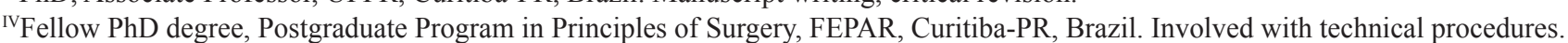

${ }^{v}$ Fellow Master degree, Postgraduate Program in Principles of Surgery, FEPAR, Curitiba-PR, Brazil. Involved with technical procedures.

${ }^{\mathrm{VI}}$ Graduate student, FEPAR, Curitiba-PR, Brazil. Involved in technical procedures

\begin{abstract}
PURPOSE: To compare controlled liver regeneration in rats submitted to $60 \%$ hepatic resection having L-arginine supplemented diet, based on weight changes of the regenerated liver, laboratory parameters of liver function and pathological findings.

METHODS: Thirty-six rats were divided into two groups, control and L- arginine. The first received standard chow and saline solution by gavage. The second had supplementation with L- arginine. Animals were killed on postoperative period at $24 \mathrm{~h}, 72 \mathrm{~h}$ and seven days. For analysis of liver regeneration was used Kwon formula for weight, laboratory tests and mitosis.

RESULTS: Weight, showed no benefit with L- arginine supplementation; however, intergroup comparison in the first $24 \mathrm{~h}$ observed positive effect on supplementation $(\mathrm{p}=0.008)$. Alkaline phosphatase was increased in arginine group ( $<<0.04)$. The number of mitoses showed no difference between the two groups; however, in the first 24 hours, the supplemented group had higher number of mitoses within the groups $(\mathrm{p}=0.03)$.
\end{abstract}

CONCLUSION: Supplementation with L-arginine did not show benefits in liver regeneration; however, supplemented group in the first 24 hours showed benefits over 72 hours and seven days of the evaluation by weight gain and number of mitosis.

Key words: Arginine. Liver Regeneration. Hepatectomy. Rats. 


\section{Introduction}

In humans, the liver regeneration following surgical resection is complete and in three months in the rat, seven to 10 days, thus establishing a good correspondence with the experimental model $^{1-3}$.

Nutrients beyond produce energy have other functions, among them stand out from the balance between degradation / tissue reconstruction and maintenance of normal body functions. Some stressful situations - sepsis, trauma and surgical procedures - cause changes in the physiological process of maintenance and control of organic normality, responding to these situations with state of hypermetabolism. In these cases the altered metabolism of glucose and protein degradation happens increased power consumption, causing situations of catabolism and cause alterations in metabolism and nutrient requirement ${ }^{4-6}$.

An amino acid that is the focus of several studies for use in situations of stress is arginine. The effect of supplementation with amino acids such as arginine, is due to the fact that these amino acids participate in the processes of ureagenesis, gluconeogenesis and protein synthesis. The liver responds to diets enriched in these amino acids by increasing the transmembrane activity, favoring the functions of the hepatic system, during the state of hypercatabolism ${ }^{7,8}$.

Enteral immunonutrition offer formulated with arginine proposes to reduce the risk of complications and infections in patients undergoing major operations and traumas 9. Aspects of physiological regulation of immunonutrition may show promise in prognosis hepatectomy, contributing significantly in the treatment of liver diseases.

The aim of this study was to evaluate liver regeneration in rats after partial hepatectomy of $60 \%$ when undergoing diet supplemented with L - arginine and analyzed by the weight change of the regenerated liver laboratory parameters of liver function and pathological study.

\section{Methods}

This study was approved by the Ethics Committee and Animal Experiments (EAEC), State University of Maranhão, São Luís, MA, Brazil under Protocol 036/12.

Thirty six rats (Rattus norvegicus Albinus, Rodentia mammalia), Wistar adult male, weighing between 195 and $330 \mathrm{~g}$ were used. The animals were housed in cages, given water and standard chow species (Purina ${ }^{\circledR}$ Labina) under temperature of $23 \pm$ $2^{\circ} \mathrm{C}$, in a airy environment without noises and kept the dark / light cycle of 12 hours.

The first or control group was fed daily and offered free water plus saline infusion $(1 \mathrm{~mL} / 100 \mathrm{~g})$ by gavage. Second, in addition to being fed with the diet was administered by gavage (to ensure receipt of the total nutrient) 15 minutes before surgery $1 \mathrm{~mL} / 100 \mathrm{~g}$ solution of $10 \% \mathrm{~L}$-arginine and an equal dose every $24 \mathrm{~h}$ till date of death. Each group was divided into three subgroups with death programmed to $24 \mathrm{~h}, 72 \mathrm{~h}$ and seven days post surgery.

The animals were manually restrained and subjected to intramuscular anesthesia on the rear face of the thigh of $40 \mathrm{mg}$ $/ \mathrm{kg}$ ketamine and $5 \% 10 \mathrm{mg} / \mathrm{kg}$ xylazine $2 \%$. Laparotomy was performed $4 \mathrm{~cm}$ from $1 \mathrm{~cm}$ below the xiphoid process with scissors. The abdominal cavity was inspected, and the liver removed $(60 \%)$ was weighed on a precision balance. The synthesis of the abdominal wall was held below.

The calculation of the rate of regeneration was based on weight and made through the formula Kwon, (1989) 10:

$$
\begin{aligned}
& \text { \% Regeneration }(\mathrm{R})=\mathrm{D} / \mathrm{E} \times 100 \\
& \text { where: } \\
& \mathrm{E}=\mathrm{R} / 0.7 \text {; } \\
& \mathrm{D}=\text { liver weight per } 100 \mathrm{~g} \text { of animal weight on the day } \\
& \text { of sacrifice; } \\
& \mathrm{E}=\text { estimated resected liver per } 100 \mathrm{~g} \text { before hepatectomy; } \\
& \mathrm{R}=\text { weight of the resected liver. }
\end{aligned}
$$

To death at $24 \mathrm{~h}, 72 \mathrm{~h}$ and seven days postoperatively, the animals were anesthetized and fixed in the surgical board.

The blood collection was made through the puncture of the caudal vein cava, picking up $4 \mathrm{~mL}$ of blood and placed in a test tube without anticoagulant dosage: aspartate aminotransferase (AST), alanine aminotransferase (ALT), gamma-glutamyl transpeptidase (GGT), phosphatase alkaline (ALP), total bilirubin, indirect bilirubin, direct bilirubin, total protein, albumin, globulin, glucose, urea and creatinine.

The death of the animal was performed by exsanguination and those where it has not occurred after this procedure, there was anesthetic overdose with four times the dose for induction of anesthesia.

Histological analysis to quantify cell replication was used hematoxylin and eosin. The slides were examined by a single pathologist.

Data were statistically analyzed using SPSS 17.0 for Windows (2007). Initially it was done the normality ShapiroWilk and only the initial and final rat weight variables, initial 
and final weight of the liver, the final percentage mouse liver and creatinine were normally distributed ( $p>0.05)$. Accordingly, we applied the test of multivariate analysis of variance (MANOVA) with two factors, group and time and then the Tukey test to posthoc comparisons over time. All variables that were not normally distributed, the nonparametric Mann-Whitney tests were applied to evaluate the effect of the group and the Kruskal-Wallis test of time. The significance level for rejecting the null hypothesis was $5 \%$, in other words, it was considered as statistically significant value of $\mathrm{p}<0.05$.

\section{Results}

In the arginine group, two animals died within the first 24 hours after surgery, before the time scheduled for your group, related to induction of anesthesia and were removed from the analysis.

The groups were comparable regarding the initial weight (animal and liver) between the two groups and within groups $(\mathrm{p}>0.05)$.

\section{Weight gain liver}

The percentage of regeneration had $\mathrm{p}<0.05$ for the control group (Table 1). In the group receiving L - Arginine, in 24 it was significantly higher when compared with other times of sacrifice within the same group.

TABLE 1 - Analysis of percentage of liver regeneration.

\begin{tabular}{lcccc}
\hline Group & Time & N & Median & P \\
Control group & & $\mathbf{1 6}$ & $\mathbf{1 1 2 . 5}$ & $\mathbf{0 . 0 1 5}$ \\
& $24 \mathrm{~h}$ & 4 & 61.3 & 0.435 \\
& $72 \mathrm{~h}$ & 6 & 161.5 & \\
& 7 days & 6 & 109.5 & \\
Arginine & & & & \\
& & $\mathbf{1 6}$ & $\mathbf{8 5 . 3}$ & \\
& $24 \mathrm{~h}$ & 6 & 50.3 & 0.008 \\
& $72 \mathrm{~h}$ & 5 & 93.3 & \\
& 7 days & 5 & 104.9 & \\
\hline
\end{tabular}

\section{Analysis of liver function}

Laboratory tests were collected on the day of animal sacrifice. In the assessment of liver function, only alkaline phosphatase showed substantially higher in the arginine group, a statistically significant manner $(\mathrm{p}<0.05$ - Table 2$)$
TABLE 2 - Assessment of liver function between groups.

\begin{tabular}{|c|c|c|c|c|c|}
\hline Variable & group & $\mathbf{N}$ & median & $\begin{array}{c}\text { Mean } \\
\text { rank }\end{array}$ & $\mathbf{p}$ \\
\hline \multirow[t]{2}{*}{ AST } & Control & 18 & 243.5 & 15.8 & 0.281 \\
\hline & Arginine & 16 & 280.0 & 19.5 & \\
\hline \multirow[t]{2}{*}{ ALT } & Control & 18 & 164.5 & 16.6 & 0.574 \\
\hline & Arginine & 16 & 194.0 & 18.6 & \\
\hline \multirow[t]{2}{*}{ GAMA GT } & Control & 18 & 5.0 & 18.2 & 0.67 \\
\hline & Arginine & 16 & 5.0 & 16.7 & \\
\hline \multirow[t]{2}{*}{ ALP } & Control & 18 & 587.0 & 14.2 & 0.042 \\
\hline & Arginine & 16 & 805.0 & 21.2 & \\
\hline \multirow{2}{*}{$\begin{array}{l}\text { Bilirubin } \\
\text { total }\end{array}$} & Control & 18 & 0.9 & 16.6 & 0.574 \\
\hline & Arginine & 16 & 1.4 & 18.5 & \\
\hline \multirow{2}{*}{$\begin{array}{c}\text { Bilirubin } \\
\text { indirect }\end{array}$} & Control & 18 & 0.3 & 17.6 & 0.986 \\
\hline & Arginine & 16 & 0.3 & 17.4 & \\
\hline \multirow[t]{2}{*}{ Bilirubin direct } & Control & 17 & 0.6 & 16.2 & 0.631 \\
\hline & Arginine & 16 & 0.9 & 17.8 & \\
\hline \multirow[t]{2}{*}{ Proteins Totais } & Control & 18 & 1.3 & 15.2 & 0.154 \\
\hline & Arginine & 16 & 1.4 & 20.1 & \\
\hline \multirow[t]{2}{*}{ Albumin } & Control & 18 & 0.9 & 15.3 & 0.187 \\
\hline & Arginine & 16 & 1.0 & 19.9 & \\
\hline \multirow[t]{2}{*}{ Globulin } & Control & 18 & 0.4 & 16.5 & 0.551 \\
\hline & Arginine & 16 & 0.4 & 18.6 & \\
\hline
\end{tabular}

Analysis of mitosis

The evaluation of liver regeneration using the number of mitotic cells in liver (Table 3 ) showed that the results in the groups were similar $(\mathrm{p}>0.05)$.

TABLE 3 - Mitosis analysis.

\begin{tabular}{ccccc}
\hline Group & Time & N & median & P \\
\hline \multirow{3}{*}{ Control } & & & & \\
& $24 \mathrm{~h}$ & 6 & 7.5 & 0.069 \\
& $72 \mathrm{~h}$ & 6 & 10.5 & \\
Arginine & 7 days & 6 & 2.0 & \\
& & $\mathbf{1 6}$ & $\mathbf{8 . 0}$ & \\
& $24 \mathrm{~h}$ & 6 & 6.0 & 0.036 \\
& $72 \mathrm{~h}$ & 5 & 10.0 & \\
& 7 days & 5 & 2.0 & \\
\hline
\end{tabular}


A review of mitosis in relation to the time of sacrifice showed that in the control group there were no intragroup differences. However, the L-arginine group was 24 in early mitosis more than 72 hours and seven days $(\mathrm{p}<0.05)$.

\section{Discussion}

In this study, as in several other studies, we used the formula Kwon, for evaluation of regeneration by the regenerated liver weight gain. This response in another study using the histamine Barbul et al..$^{10}$, using the formula Kwon, 36h, three and seven days after partial hepatectomy of approximately $67 \%$, which showed regeneration Liver weight was similar to $36 \mathrm{~h}$. By the third day it could be seen that both groups had partially recovered liver mass and on the seventh day both had regenerated more than the initial mass, with no significant difference between groups. Kwon et al. ${ }^{11}$, author of the formula, in evaluating the effect of fibrinogen on liver regeneration, also used to define the weight if happened or not.

OG Son et al. ${ }^{12}$ showed a statistically significant increase in the remaining liver in evaluation of immunosupression-induced extensive hepatectomy in rats tacrolimus. In both groups (study / control), the first 24 hours and on the seventh day after hepatectomy was possible to demonstrate this result. When comparing the results between groups, animals receiving tacrolimus showed a higher rate of liver regeneration, reaching statistical significance when compared to the subgroup of animals kept placebo.

This work to evaluate regeneration by weight of the animal, could not confirm the benefit of L-arginine on liver regeneration compared to the control group. This group had better results than arginine until the period studied. Regarding the day of sacrifice of animals (24h, $72 \mathrm{~h}$ and seven days), significant effect of supplementation of L-arginine was observed in the first 24 hours, compared to other periods in this group, with statistical significance $(\mathrm{p}=0.03)$. This fact can be interpreted as that L-arginine can promote liver regeneration more effectively in the first 24 hours postsurgery. The control group showed no differences between regeneration periods.

Kurokawa T et al..$^{13}$ evaluated the effect of $\mathrm{L}$ - arginine on liver regeneration process through the liver weight of $70 \%$ hepatectomized mice. No difference was observed in groups such as in this study. The methodology for measuring weight gain in the two studies showed different results despite semelhantes.

When compared to liver function between control and arginine groups of this study, no result stating benefits of supplementation of L-arginine was observed.
There was a significant difference $(\mathrm{p}<0.05)$ elevation of alkaline phosphatase in the supplemented group. As it increases when there is proliferation or cell renewal, it can be inferred benefits of L-arginine, which deserves further clarification.

Resections of the liver can lead to acute liver failure. In the study with $70 \%$ hepatectomy, the liver function tests remain within normal limits. Evaluation of liver regeneration after portal hypertension, showed that there were changes in the remnant liver related to cholesterol, total protein, albumin and globulin and prothrombin time activity. Transaminase levels (ALT and AST), alkaline phosphatase, gamma glutamyl, blood glucose, bilirubin and APTT showed values within the normal 14. Similarly in this study, even with extensive hepatectomy, no changes of the parameters of AST, ALT, bilirubin and glucose was observed.

The liver when damaged by disease or surgical procedures, has great capacity for growth by compensatory hypertrophy and hyperplasia of the remaining wolves. The number of mitotic cells in the organ increases approximately 600 times, 24 hours after partial hepatectomy in rats $67 \%{ }^{15}$.

The mitotic index is commonly used to determine the result of regeneration. BB Melo et al. ${ }^{15}$ in evaluating liver regeneration, where the effect of omeprazole and pantoprazole in hepatectomized rats was tested, the mitotic index was used to determine the result. They showed no significant difference between groups. In this work, the number of mitoses was used to assess regeneration, but also failed to show benefit with the use of L-arginine, when compared to the control group.

Under normal circumstances in human liver regeneration starts within three days and the body reaches its original size 3-6 months. In rats, the interval between partial hepatectomy and initiation of DNA synthesis in hepatocytes peak is $10-12 \mathrm{~h}$ and about 24 . The weight of the liver is completely recovered by the seventh day. Mitosis begins on the first day and cell division is completed in the second and third days ${ }^{16}$.

Three to four days after liver resection, the mitotic activity of hepatocytes is greatly diminished. The periportal hepatocytes has clusters of 10-14 (clusters) without sinusoids or extracellular matrix. Groupings exist in hepatocytes at the periphery of the group and in contact with sinusoids. Inside the hepatocyte clusters exist without contact with the vascular surface ${ }^{17}$. In this study we observed this relationship in the group that was supplemented with L-Arginine. The number of mitoses was significantly higher in the first 24 hours ( $p<0.05$ ) when compared $72 \mathrm{~h}$ and seven days in the same group. In the control no difference between the subgroups was observed. 


\section{Conclusions}

Although the two groups occurred liver regeneration, could not confirm benefits with supplementation of L-arginine. It is worth noting that with the arginine in 24 , this benefit was measurable when we calculated the regenerated liver weight gain and number of mitosis, but he remained at $72 \mathrm{~h}$ and seven days in the assessment.

\section{References}

1. Torres OJM, Pantoja PB, Barbosa ES, Melo LAL, Miranda-Filho AR, e Júlio Cezar Uili Coelho JC. Hepatic resections: an initial experience and medium term follow-up. ABCD Arq Bras Cir Dig. 2004 Jan/Mar; 17(1):3-7.

2. Torres OJM, Hoffman II, Coutinho 1S, Cintra JCA, Almeida Júnior LB, Arraes LRG, Dominici AJ. Central hepatectomy: case report. ABCD Arq Bras Cir Dig. 2005 Jan/Mar; 18(1):30-2.

3. Skandalakis JE, Skandalakis LJ, Skandalakis PN, Mirilas P. Hepatic surgical anatomy. Surg Clin North Am. 2004 Apr;84(2):413-35, viii. PMID: 15062653.

4. Guimarães FA, GuimarãesSB, Vasconcelos PRC, Vasconcelos PRL. Effects of L-alanyl-glutamine on blood and liver of rats submitted to partial hepatectomy. Braz J Clin Nutr. 2004 Apr/Jun;19(2):54-8.

4. Barbosa RC, Guimarães SB, de Vasconcelos PR, Chaves CR, de Vasconcelos PR. Metabolic effects of 1-alanyl-glutamine in burned rats. Burns. 2006 Sep;32(6):721-7. doi: 10.1016/j. burns.2005.12.014.

5. Kleiman I, Simões MJ, Goldenberg S. Current aspects of the wound healing process. Acta Cir Bras. 1987;2(1):19-21.

6. Sales RP, Miné CEC, Franco AD, Rodrigues EL, Pelógia NCC, Silva RS, Cogo JC, Martins RABL, Osorio RL, Ribeiro W. Acute Effects of supplementation aspartate arginine on muscle fatigue in trained volunteers. Rev Bras Med Esporte. 2005 Nov/Dec;11(6):347-51. doi: 10.1590/S1517-86922005000600008.

7. Visek WJ. Arginine and Disease States University of Illinois College of Medicine at Urbana-Champaign, Urban. 1985;61801:532-41.

8. Senkal M, Mumme A, Eickhoff U, Geier B, Späth G, Wulfert D, Joosten U, Frei A, Kemen M. Early postoperative enteral immunonutrition: clinical outcome and cost-comparison analysis in surgical patients. Crit Care Med. 1997 Sep;25(9):1489-96. PMID: 9295822.

9. Barbul A, Fishel RS, Shimazu S, Wasserkrug HL, Yoshimura NN, Tao RC, Efron G. Intravenous hyperalimentation with high arginine levels improves wound healing and immune function. J Surg Res. 1985 Apr;38(4):328-34. PMID: 3923266.

10. Kwon AH, Uetsuji S, Yamamura M, Hioki K, Yamamoto M. Effect of administration of fibronectin or aprotinin on liver regeneration after experimental hepatectomy. Ann Surg. 1990 Mar;211(3):295300. PMID: 1689991

11. Filho OG, Toderke EL, Baretta GA, Sakamoto DG, Agulham MA, Tambara EM, Matias JE. Tacrolimus-based immunossuppresion favours liver regeneration induced by extent hepatectomy in rats. Rev Col Bras Cir. 2010 Jun;37(3):218-25. doi: 10.1590/S010069912010000300010

12. Kurokawa T, An J, Tsunekawa K, Shimomura Y, Kazama S, Ishikawa N, Nonami T, Sugiyama S. Effect of L-arginine supplement on liver regeneration after partial hepatectomy in rats. World J Surg Oncol. 2012 May 31;10:99. doi:10.1186/1477-7819-10-99.
13. Aguiar LRF, Nassif PAN, Ribas CAPM, Czeczko NG, Ribas MM, Marinho Junior $\mathrm{CH}$, Wendler E. Liver regeneration after partial hepatectomy in rats submitted to post-hepatic portal hypertension. ABCD Arq Bras Cir Dig. 2011 Apr/Jun;24(2):144-51. doi: 10.1590/ S0102-67202011000200011.

14. Melo BB, Silva RL, Fakhouri F, Melo VA, Lima SO. Effect of omeprazole and pantoprazole on liver regeneration after partial hepatectomy in rats. Acta Cir Bras. 2003 Nov/Dec;18(6):542-4. doi: 10.1590/S0102-86502003000600011.

15. Tannuri AC, Tannuri U, Coelho MC, Santos NA, Mello ES Experimental models of hepatectomy and liver regeneration using newborn and weaning rats. Clinics (Sao Paulo). 2007 Dec;62(6):75762. doi: 10.1590/S1807-59322007000600016.

16. Godoy JL, Matias JEF, Coelho JCU. Liver regeneration: Prometheus' myth revisited. JBT J Bras Transpl. 2006 Apr/Jun;9(2):535-9.

\section{Correspondence:}

Widlani Sousa Montenegro

Faculdade Evangélica do Paraná (FEPAR)

Rua das Orquídeas, Condomínio Villagio Jardins 3, casa 13

65072-561 São Luís - MA Brasil

Tel.: (55 98)8814-2010

widlanienfa@hotmail.com

Received: Apr 15, 2014

Review: Jun 17, 2014

Accepted: July 14, 2014

Conflict of interest: none

Financial source: none

${ }^{1}$ Research performed at Postgraduate Program in Principles of Surgery, FEPAR, Curitiba-PR, Brazil. Part of Master degree thesis, Postgraduate Program in Health Sciences, Health Sciences Faculty, UnB. Tutor: Prof. Osvaldo Malafaia. 